\title{
PROJECT ANQA: PRESENTING THE BUILT HERITAGE OF DAMASCUS, SYRIA THROUGH DIGITALLY-ASSISTED STORYTELLING
}

\author{
Francesca Brzezicki ${ }^{1}$, Rufino R. Ansara ${ }^{1}$, Reem Awad ${ }^{1}$, Mario Santana Quintero ${ }^{1}$, Samir Abdulac ${ }^{2}$, Marie-Laure Lavenir ${ }^{2}$, Burcu \\ Tung $^{3}$, John Ristevski ${ }^{3}$ Maureen Pelletier ${ }^{2}$ \\ ${ }^{1}$ Carleton Immersive Media Studio (CIMS), Carleton University, 1125 Colonel By Dr, Ottawa, ON K1S 5B6, \\ f.brzezicki@gmail.com,rufinoansara@gmail.com, ReemAwad@cmail.carleton.ca, Mario.santana@carleton.ca \\ ${ }^{2}$ International Council on Monuments and Sites, 11 rue du Séminaire de Conflans, 94220 Charenton-le-Pont, abdulac@wanadoo.fr, \\ marie-laure.lavenir@icomos.org, maureen.pelletier@icomos.org \\ ${ }^{3}$ Cyark, 449 15th Street, Suite 304, Oakland, CA, 94612 USA burcu.tung@cyark.org, john.ristevski@cyark.org
}

\section{Commission II, WG II/8}

KEY WORDS: 3D documentation, Photogrammetry, Heritage places and data at risk, Virtual Museums, Syria, Middle East, Project Anqa

\begin{abstract}
:
There is a growing interest in using new technology to create high-quality $3 \mathrm{D}$ recordings of heritage sites at potential risk of damage from conflict or natural disaster. Project Anqa is a multi-partner initiative to digitally document and present seven such at-risk heritage sites, all of which are located in Damascus, Syria. Through a training program, we enabled Syrian locals to collect a variety of data from all seven sites. With this data - a combination of photographs, laser-scan data and audio interviews - we present a webapplication that provides researchers and the public a visually rich experience that showcases these at-risk sites. We term this approach "digitally-assisted storytelling." Our goal is to raise awareness of the need to document and preserve at-risk heritage in the Middle East while providing local professionals in the region with the skills to carry out these tasks. Furthermore, Project Anqa aims to be an educational resource for both researchers and the public. By allowing all collected data to be downloaded at no charge through an open access platform, we encourage the transfer of knowledge and information while preserving the digital longevity of this endeavour.
\end{abstract}

\section{INTRODUCTION}

\subsection{Background}

Project Anqa (CIMS Development Team, 2018) is a multipartner initiative to digitally document and present seven at-risk heritage sites located in Damascus, Syria. The project is supported by the Arcadia Fund and was completed with the collaboration of the Syrian Directorate of Antiquities and Museums (DGAM), CyArk, the International Council on Monuments and Sites (ICOMOS), Carleton Immersive Media Studio (CIMS), Mitacs and Yale University.

Project Anqa was spearheaded by Yale University (Akhtar et al., 2017) and transferred to CIMS in 2018. All the data presented in the project was collected by DGAM members who were trained in Beirut by CyArk and Yale researchers. The captured data included photographs, videos, laser-scan data and audio interviews with caretakers and individuals who use each of the seven sites. We used these elements to create a webapplication that provides researchers and the public a visuallyrich experience combined with informative textual descriptions of each site. At CIMS, this method of creatively using digital heritage documentation to share architectural history with the public is termed "digitally-assisted storytelling."

Project Anqa is intended not only to make these sites available to those who cannot access them due to the ongoing conflict, but to build skills and knowledge among local professionals in the region and to raise awareness of the existence and value of Syrian built heritage.
The current Anqa project was developed with a multidisciplinary team at CIMS including architecture, history and information technology streams.

\subsection{Documenting Heritage in Areas of Conflict}

Damascus is one of the oldest cities in the Middle East, founded in the 3rd millennium B.C. The ancient city of Damascus was inscribed as a UNESCO World Heritage Site in 1979; however, in 2013, Damascus Ancient City was added to UNESCO's list of World Heritage in Danger (which includes all heritage sites in Syria). UNESCO designed the World Heritage in Danger list to inform the wider community of the conditions that threaten World Heritage, and to raise awareness of the need to take action in protecting endangered heritage.

Since the Syrian conflict began in 2011, many heritage sites have been targeted, damaged, or destroyed by fighting. In November 2015, the DGAM met with UNESCO to discuss damage assessment in Syria. In April 2016, UNESCO called for unity and coordination to protect Syrian cultural heritage. Interviews with individuals who manage or work at the sites covered by Project Anqa indicated that these sites have not suffered serious damage due to the Syrian conflict. However, training locals to document their heritage is necessary at all times, and even more so in the event of conflict where cultural heritage is on the front line of casualties. 


\subsection{Proposed Methodology}

This paper presents an overview of the initial data collection, an in-depth analysis of the seven sites documented, and a description of the final web-application.

\section{RELATED WORKS}

\subsection{Documentation of cultural heritage through Photogrammetry, Laser Scanning and Other Novel Technologies}

Recently, there have been significant efforts to use new technologies to capture heritage sites digitally for conservation and to create posterity records. The resulting digital documentation (Howell, 2017) can be combined with historical research and explanatory text and presented to the public in the form of digitally-assisted storytelling (Ouimet, 2015). Much of this work has used technologies such as photogrammetry, laser scanning (Yastikli, 2007), and Unmanned Aerial Systems or drones (Federman, 2018) to capture and disseminate information about built heritage in an engaging and dynamic way.

The use of these novel technologies allows for the greater exposure of these endangered heritage sites - many people do not have access to these areas because of the ongoing regional conflicts. It is important to raise awareness of the existence and value of those locations as they present a real, tangible way of visualizing and experiencing history and progress in a geographic area (Yilmaz et al. 2007).

\subsection{Virtual Tours as an Example of Digitally-Assisted Storytelling: Using Digital Documentation of Built Heritage to Create an Architectural Narrative}

One approach of documenting heritage sites is to capture them as 360-degree panoramic digital photographs through which a user can navigate (Ciurea, 2016). Google Heritage displayed this method through their online virtual tours, created in collaboration with CyArk (Google, 2019).

A notable example of the use of virtual tours to present heritage architecture is the Senate of Canada Virtual Tour (Dhanda et al, 2017), created by CIMS to permit Canadians and tourists to see the Senate Chamber during the ten-year closure and rehabilitation of the physical building. There have also been opportunities to transform these tours into virtual reality experiences, meant to further immerse viewers into the area at hand (Graham et al, 2017). Additional information is provided to the viewer with either written text or recorded audio as needed, thus allowing the viewer to not only observe built heritage but also learn about its background and function as part of the cultural landscape.

\subsection{The Dissemination of Knowledge in Heritage Conservation}

One of Project Anqa's main goals was to provide technical training to locals to allow them to conduct the heritage documentation and digitization themselves. Researchers have expressed the need to provide better, or more targeted, training for those in the field to allow them to use new technologies to their full capacity (Santana Quintero, 2007). It is an ethical obligation to not only capture digital data of heritage places at risk with advanced devices, but also to provide adequate capacity to local teams to be able to document their heritage, making the documentation more sustainable at long term. This a better alternative to having foreign teams parachuting into sites and recording them on the behalf of the locals.

Furthermore, with trained locals, the challenges of site accessibility that may affect and delay the process of digital documentation can be overcome with locals conducting heritage documentation themselves. We must bear in mind that locals have better knowledge of the site's political and social conditions, safety concerns, and will often have a wider time frame to complete all tasks, particularly compared to foreign teams.

\section{METHODOLOGY}

Project Anqa (Figure 1) is a web-enabled platform that permits visitors to explore a variety of heritage sites located in Damascus, Syria. It combines a virtual tour technology with photogrammetry, laser scan data and written text to provide a well-rounded exposition of the data. All the content collected by the DGAM members is also available for download through a portal called Dataverse.

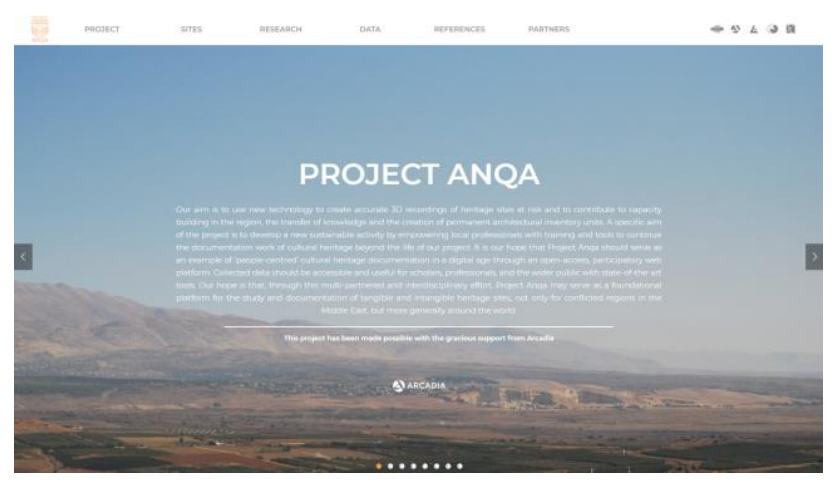

Figure 1. Anqa Project - Home Page

\subsection{The Documented Sites}

With the data provided by DGAM, we were able to present a total of seven (7) sites. These sites were chosen to provide a varied illustration of the different functional forms of structures present in the area. These types include housing, education, health-care, bath, commercial and religious. Specifically, the sites are:

- $\quad$ Al-`Azm Palace

- Ananias Chapel

- Bimaristan Nur al-Din

- Hammam Nur al-Din

- Khan As'ad Pasha

- Madrasa al-Jaqmaqiya

- Tekkiye Süleymaniye

The information in the following sections is provided in the virtual tours:

\subsubsection{Al-'Azm Palace}

Al-'Azm Palace was built between 1749-1751 (1163-1165 AH) by governor of Damascus As'ad Pasha al-'Azm is one of the most important and beautiful examples of domestic architecture in Damascus (Daskalakis, 2004). 
As'ad, unlike any other imperial official in the city, governed for fourteen consecutive years (1743-1757 AD/1156-1170 AH) and was not a foreign transplant but hailed from a Syrian family destined to have a long history in leadership. While the entire 'Azm family made their mark on Damascus, architectural projects were a special focus of As'ad's leadership: he also built the Khan As'ad Pasha, as well as numerous other construction and restoration projects in Damascus and along the Hajj pilgrimage route (Shamir, 1963).

In 1983 (1403 AH), Al-'Azm Palace was given an Agha Khan Award for Architecture in honour of its sensitive restoration and the continuing commitment to its maintenance (Sherban, 1985). The palace now houses the Museum of Arts and Popular Traditions and is a historic site open to visitors.

\subsubsection{Ananias Chapel}

Ananias Chapel is a small underground chapel located in the former Christian quarter of Damascus, near two of the ancient gates of the old city, Bab Touma and Bab Sharqi. Damascus was an important site of early Christianity, and numerous local legends exist linking Biblical figures to the city. What began as a small community of believers expanded until, by the Council of Nicaea in 325 (308 BH), Damascus was able to send its bishop to attend the proceedings (Burns, 2005). One of the greatest ties connecting Damascus to Christianity undoubtedly exists at Ananias Chapel, the site traditionally associated with the conversion of Saul of Tarsus (Paul the Apostle) to Christianity. It remains today as an important pilgrimage site for Christians.

\subsubsection{Bimaristan Nur al-Din}

The Bimaristan Nur al-Din, constructed in 1154 (549 AH) is the earliest surviving example of an Islamic hospital. It was built by Nur al-Din Mahmud ibn Zengi, ruler of Syria from 1146-1174 (540-569 AH) through a waqf, a charitable endowment meant to fund public and religious institutions. The word "bimaristan" is of Persian origin, meaning "place of the sick," and the building functioned as both a hospital and medical school.

This was not the first hospital in Damascus, as one was established by Al-Walid I in 706 (88 AH); however, according to traveller Ibn Jubayr, the Bimaristan Nur al-Din was larger and better built. An extension to the bimaristan was added in 1242 (639 AH) by a doctor, Badr al-Din, in order to accommodate more patients, and a subsequent restoration was completed in 1283 (682 AH). It continued to be used as a hospital until the early 20th century (early 14th century AH), when it was replaced by a modern facility.

The building was restored by the Directorate General of Museums and Antiquities in 1979 (1399 AH) and remains in good condition. It now functions as the Museum of Medicine and Science in the Arab World.

\subsubsection{Hammam Nur al-Din}

This hammam, constructed between 1154-1174 (549-569 AH) by Nur al-Din Mahmud ibn Zengi, ruler of Syria from 11461174 (540-569 AH), is still a functioning bathhouse today. It was established to provide funds for the waqf, or charitable endowment, which supported the Nur al-Din Madrasa (built $1167 / 563 \mathrm{AH})$. The hammam was used regularly until the early 20 th century (14th to 15 th century $\mathrm{AH}$ ), when it was converted to a warehouse for soap and spices.
In 1979 (1399 AH), a request was sent to the Directorate General of Antiquities and Museums to rehabilitate the building to function as a hammam once again. Renovations lasted for approximately two years, and included restoring the dome of the mashlah. Today the Hammam Nur al-Din continues to reflect the historic importance of water in the Islamic world, both for cleanliness and as a symbol of prosperity and good living.

\subsubsection{Khan As‘ad Pasha}

The Khan As'ad Pasha (built 1751-1752/1164-1165 AH), which has been called "the great masterpiece of Ottoman Damascus," is a striking example of late Ottoman architecture in Syria.

Its patron, As'ad Pasha al-'Azm, was part of the powerful 'Azm family who governed Damascus and the Syrian provinces multiple times throughout the 18th and early 19th centuries (12th to 13th centuries $\mathrm{AH}$ ). As'ad himself had the distinction of governing Damascus for fourteen consecutive years (1743$1757 \mathrm{AD} / 1156-1170 \mathrm{AH}$ ), the only Ottoman official to do so. A shrewd leader, he built his khan at a time of high economic activity in the city, likely seeking to benefit from this increased prosperity.

By the 1970s (1390s AH), the Khan As'ad Pasha was being used as storage space for merchants in Al-Buzuriya Souq. The Department of Museums and Antiquities purchased the khan and began restoring it in $1980(1400 \mathrm{AH})$ to reconstruct the missing domes and strengthen the piers supporting them, as well as restore interior finishes and decoration, such as the gypsum decoration in the dome interiors. Although there was an attempt to transform the khan into a hotel, today it functions as a centre for cultural activities.

\subsubsection{Madrasa al-Jaqmaqiya}

The Madrasa al-Jaqmaqiya was built for the Mamluk governor of Damascus, Jaqmaq al-Arghunshawi, between 1418-1420 (821-823 AH). Located just north of the Umayyad Mosque, it was built on the site of an earlier madrasa damaged during Timur's invasion of Damascus in 1401 (803 AH).

Although a madrasa is usually defined as an Islamic religious school, historically a madrasa was a multi-function building which might also incorporate a mosque, or as in this case, a mausoleum for its patron, in addition to teaching space and lodgings for students. Damascus, which was second only to Cairo during the Mamluk sultanate and a historical centre of learning, had 128 madrasas in this period according to Abd alQadir al-Nu'aymi. The Madrasa al-Jaqmaqiya, embellished with ablaq masonry and a band of monumental inscription, is a typical example of the Mamluk appreciation for the symbolic power of architecture, extending even to the exterior of buildings which were usually left plain in Islamic urban settings.

The Madrasa al-Jaqmaqiya has undergone several changes since its initial construction: three rooms were added to the upper level in the 19th century (13th to 14 th century AH), and the building suffered bomb damage to its walls and roof during the Second World War. It was last restored in 1956 (1375 AH) by the Directorate General of Antiquities and Museums in Syria. Today, the Madrasa al-Jaqmaqiya houses the Museum of Arabic Calligraphy, the only one of its kind in Syria. 


\subsubsection{Tekkiye Süleymaniye}

The Tekkiye Süleymaniye is a mosque complex designed by the renowned Ottoman architect Sinan for Sultan Süleyman the Magnificent in 1553-1554 (960-961 AH). Located outside the city of Damascus at the time of its construction, the Tekkiye Süleymaniye was built to provide services for caravans making the Hajj, or pilgrimage to Mecca: here, in the countryside just west of Damascus, pilgrims could rest before continuing their long journey into the desert.

The Tekkiye comprises a mosque and a range of public facilities including a soup kitchen, stables, and a small number of travellers' lodgings, likely intended for special guests making the Hajj. A madrasa and market were added to the complex in 1560 (967 AH) by Sultan Selim II. The Tekkiye is arranged around a courtyard and central ablution pool, and framed by the mosque to the south, rows of guest rooms to the east and west, and stables and soup kitchen to the north. The madrasa and market are located east of the main complex.

Through this decidedly imperial architecture, Süleymanwhose father Selim I had gained control of Syria in 1516 (922 $\mathrm{AH}$ - could demonstrate personal piety and beneficence while symbolizing the new regime of Ottoman power in Syria. The Tekkiye Süleymaniye was restored by the Directorate General of Antiquities and Museums in the 1960s (1380s AH).

\subsection{Capacity Building and Data Acquisition}

As per Yale's work (Akhtar et al, 2017), one of Project Anqa's main goals was to allow locals to learn about the documentation process and perform it themselves. CyArk and Yale successfully hosted two training sessions for DGAM members in Beirut, Lebanon in 2016 and 2017. This allowed them to go to the sites mentioned above and perform all the documentation work themselves - without foreign assistance. This data is used across the Anqa website and is available for download through our Dataverse portal (see section 3.6).

\subsection{The Virtual Tour}

We used KRPano (KRPano Development Team, 2010) to create a virtual tour for each of the seven sites mentioned above. Figure 2 showcases the Ananias Chapel virtual tour.

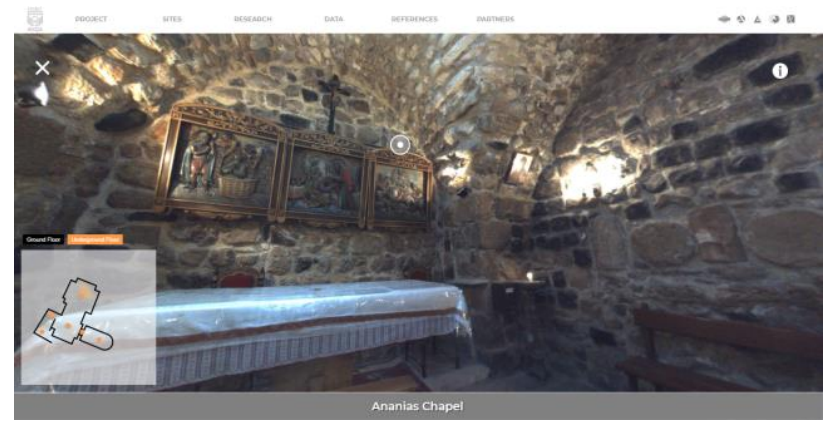

Figure 2. Ananias Chapel - Virtual Tour

Visitors to the tour can use their mouse to rotate the panorama, effectively giving them a stationary, 360-degree view of the space presented. They can jump between the different areas by clicking on the "footprints" scattered around the panoramas. The white bar at the top provides quick navigation through the different sections of the website and permits users to view the other virtual tours. The map in the bottom-left corner allows them to jump to any location available in the tour (Figure 3 ). Within this floor plan, the current location is shown with a cone-shaped area that illustrates the current camera's viewangle. Visitors are also able to click on the map to expand it or minimize it, giving them a more detailed view of the featured area.

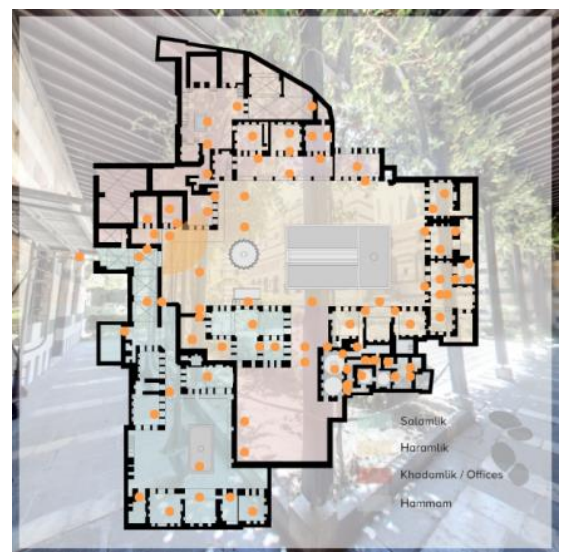

Figure 3. Al-'Azm Palace - Interactive Map

The virtual tour also features key areas, called "hotspots", marked directly on the panoramas with white circles (Figure 4). When clicked, they open a window that provides in-depth information about that location or element. Figure 5, showcasing the inlaid marble features of the Madrasa alJaqmaqiya, illustrates how this is presented. To enrich the experience, when the data was available, we generated additional 3D animations of the element at hand from the point clouds provided (as seen in Figure 5).

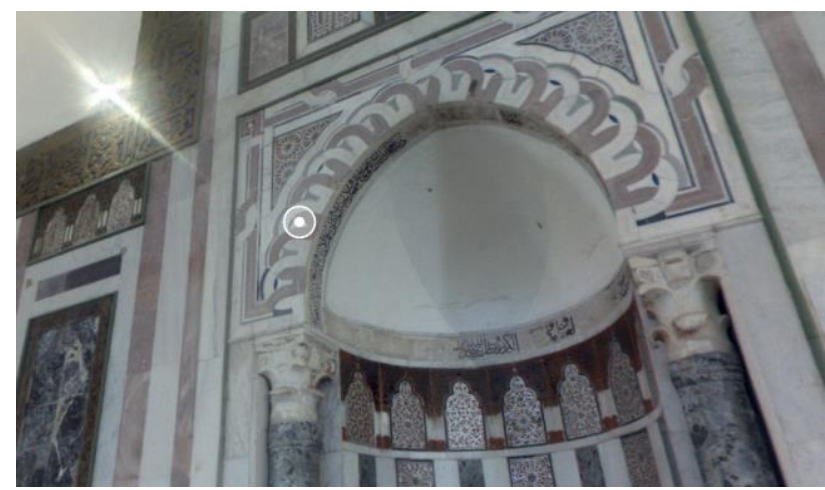

Figure 4. - Madrasa al-Jaqmaqiya - Virtual Tour Hotspot, Inlaid Marble (Panorama) 


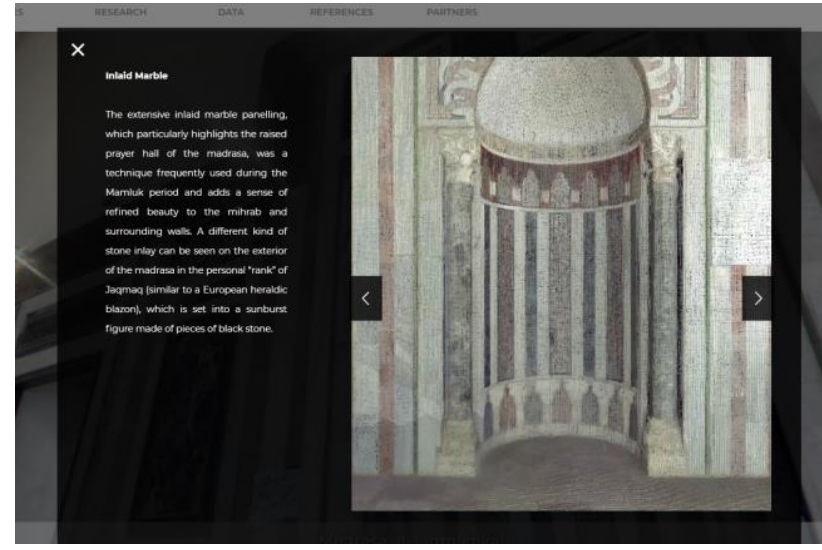

Figure 5. • Madrasa al-Jaqmaqiya- Virtual Tour Hotspot, Inlaid Marble (More Information)

\subsection{Point Cloud Animations}

DGAM was able to provide digital scans for five (5) out of the seven (7) sites. To bring these sites to life, we created visually impactful 3D animations that automatically play when users open a virtual tour (Figure 6).

We used a variety of applications to create each of these animations. These include Cloud Compare, Autodesk Recap, Autodesk 3Ds Max and Adobe After Effects CC. Each video presents a quick fly-through the entrance of each site, ending by orienting the user to where the 360-degree panorama tour begins. This allows visitors to get acquainted with the area and encourages them to explore.

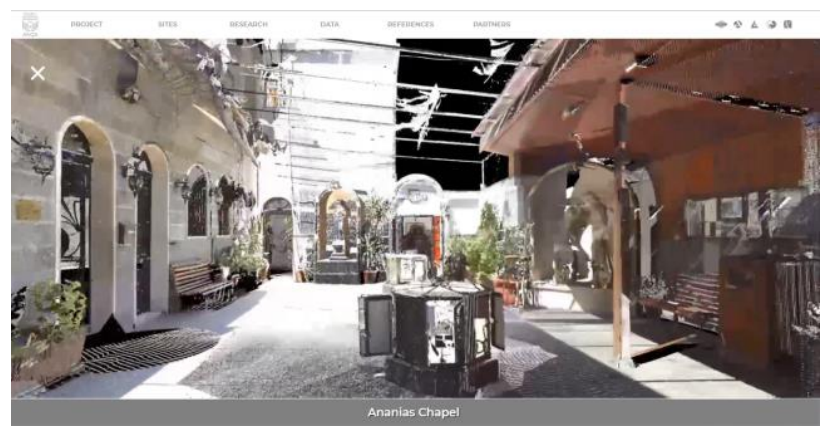

Figure 6. Ananias Chapel - Point Cloud Animation

Cyark provided the CIMS research team with a registered e57 file for each of the six sites. Each one of these files included multiple scans taken in different locations around the site, creating a complete $3 \mathrm{D}$ point cloud model. We used Cloud Compare (Figure 7) to reduce the size of the files to improve efficiency - effectively reducing the overall loading and rendering times.

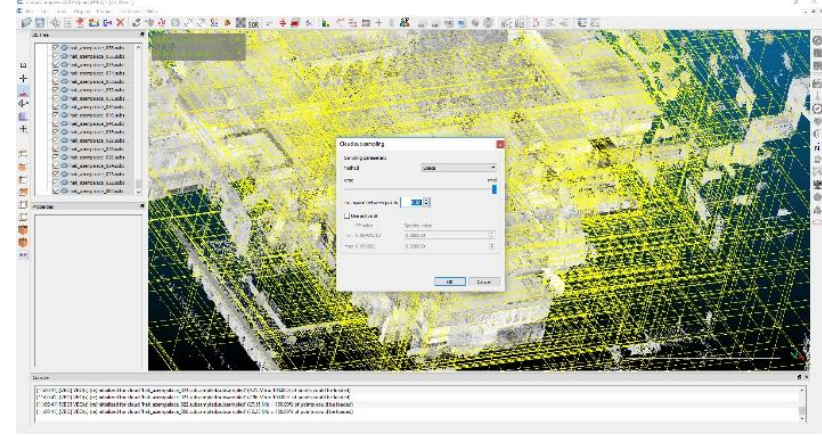

Figure 7. Al-‘Azm Palace - Using Cloud Compare to reduce point density

We brought these registered scans into Autodesk Recap (Figure 8 ), where we were able to control which scans to display, edit or delete. We removed non-essential elements and exported the models in .rcp format - these were later imported into Autodesk 3Ds Max to begin the animation process.

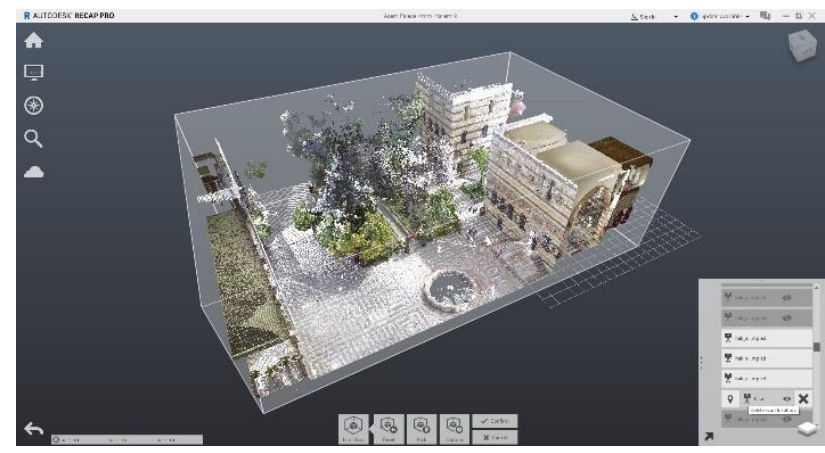

Figure 8. Al-'Azm Palace - Autodesk Recap

In Autodesk 3Ds Max (Figure 9), we created a spline that defined the camera's path through the site and set the speed. Using Mental Ray, we rendered the hundreds of frames required to generate the final video product. We accomplished this with Adobe After Effects CC (Figure 10), where we combined all the frames and exported them as a single MP4 file. This file had to be further compressed to improve network performance.

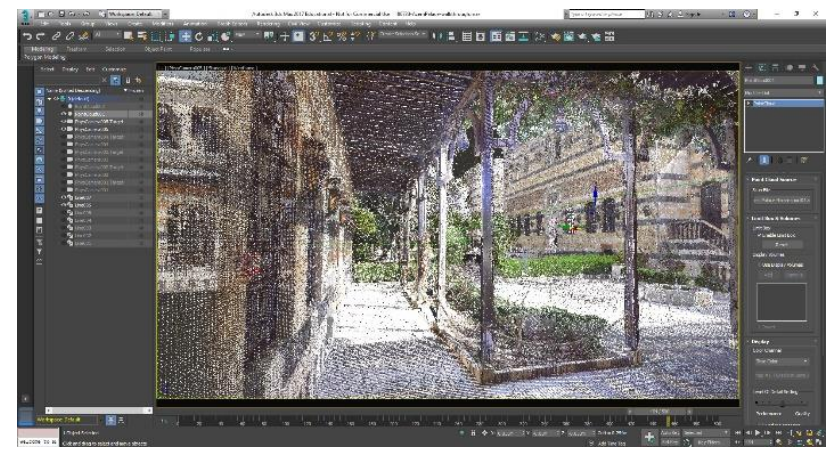

Figure 9. Al-`Azm Palace - Autodesk 3Ds Max 


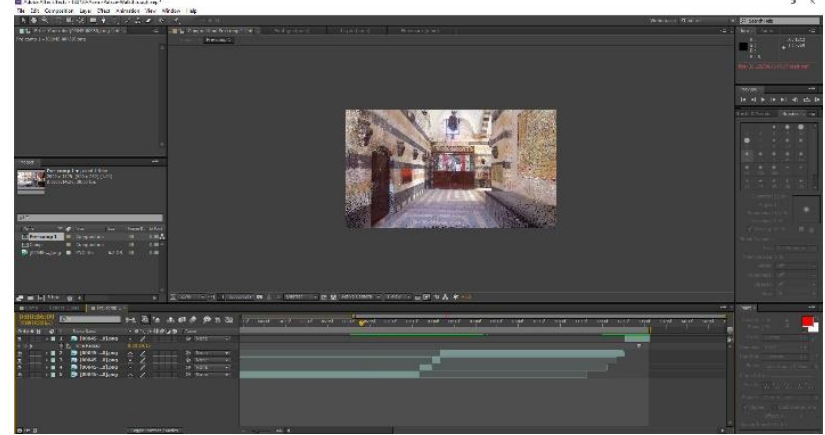

Figure 10. Al-‘Azm Palace - Adobe After Effects CS6

\subsection{Interactive Map}

We implemented an interactive map that shows visitors where each heritage site is located within Damascus (Figure 11). This feature is intended to facilitate an understanding of the basic landscape of Damascus, as well as to display where the sites are in relationship to each other. For example, a visitor exploring the tours of Al-'Azm Palace and the Khan As'ad Pasha, both built by As'ad Pasha al-'Azm, can see how closely built they are, reflecting the density and prominence of As'ad's building campaign. Including this map is another aspect of the digitallyassisted storytelling approach.

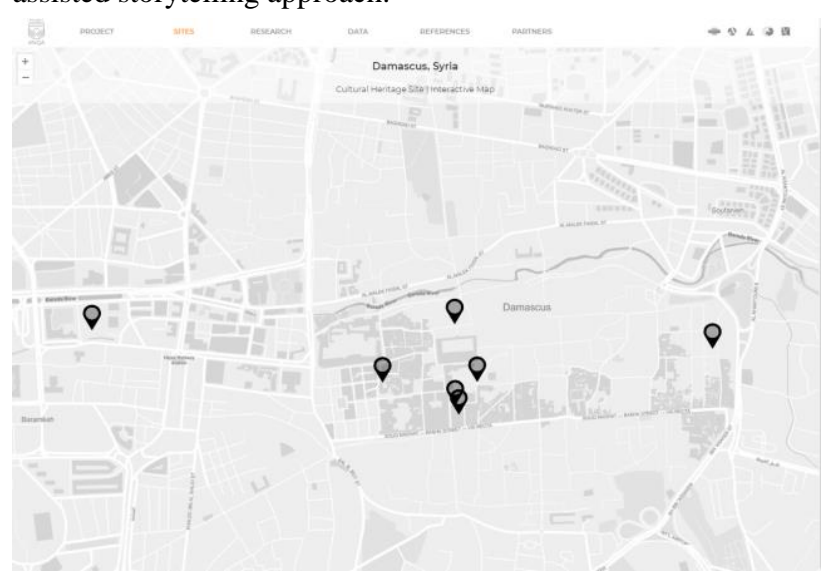

Figure 11 - Interactive Map of Damascus

\subsection{Open-Access Data}

One of the overarching goals of Project Anqa was to make all the collected data available for download and use through an online portal with appropriate metadata.

The portal chosen is Scholars Portal Dataverse (Figure 8), which is maintained by a network of Ontario (Canada) university libraries. This portal allows anyone around the world to have access to the entirety of the collected data. The aim of this platform is to permit researchers to easily reference, use and share this data with peers. The user can download any dataset, acknowledging that the data is provided for non-commercial use only.

Clicking the Data title on the upper banner of the Anqa website takes the user to a page with the seven sites; each is linked to the Dataverse portal. Each of the sites' dataverses has three datasets which include the different data available for the site where applicable: panorama data, photogrammetry dataset and Lidar dataset.

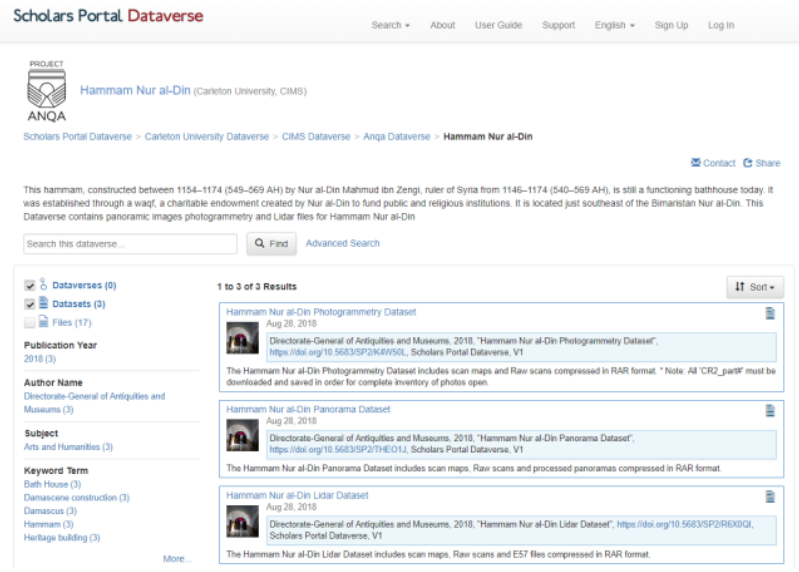

Figure 12 - Dataverse Portal for the Hammam Nur al-Din

Given that the Dataverse portal is managed by the research libraries of Ontario, the longevity of the digital records is guaranteed for decades. This meets the need of making heritage information transcend through time for the enjoyment of present and future generations.

\section{CONCLUSION}

Project Anqa, an interactive web application that combines panoramas, laser scans and text, allows the public to experience seven (7) important and at-risk sites located in Damascus, Syria.

This project has accomplished important ICOMOS Ethical principles, such as the obligation of experts to 'assist in preparedness and post-disaster as well as resilience activities to protect cultural heritage' and to 'ensure the transmission to future generations' (ICOMOS 2014).

In addition, important capacity building activities were produced out of this work, making the project viable and sustainable in the long term.

\subsection{Future Work}

We can suggest the following improvements to the work already put forward in Project Anqa:

\subsubsection{Data quantity and quality}

New iterations of the website would benefit from having more data of better quality. The exterior of the sites can be further documented and the overall quality of the panoramas and point clouds would allow us to provide a better overall experience to visitors.

Each tour's coverage of the sites varies depending on the data provided by DGAM. For example, Tekkiye Süleymaniye 360 photographs were only taken for the exterior of the mosque this means that the user does not have access to the interior of the mosque. In contrast, Al-'Azm Palace's data consisted of over two hundred 360-degree photographs covering most of Palace exterior and interior spaces including the roof. 


\subsubsection{Mobile Support}

The current website does not support mobile devices - it would be beneficial to leverage mobile capabilities to increase the overall accessibility and appeal of Project Anqa.

\subsubsection{Virtual Reality}

As mentioned in the Related Works section, adding virtual reality support would be an exciting avenue to explore - does it improve a visitor's immersion and engagement with the content presented?

\section{ACKNOWLEDGEMENTS}

We would like to thank the Syrian Directorate-General of Antiquities and Museums (DGAM), CyArk, International Council on Monuments and Sites (ICOMOS), and Yale for their involvement in the project. Their support was invaluable to the success of Anqa.

This project was graciously funded by Arcadia, a charitable fund of Lisbet Rausing and Peter Baldwin. We also thank Mitacs for providing an intern from Globalink program that supported the development of the ANQA project.

Finally, we would like to acknowledge the support of George Duimovich from Carleton's MacOdrum Library, who facilitated the use of The Scholars Portal Dataverse to host the project's data, and Laurie Smith and the Carleton Immersive Media Studio (CIMS) staff for their continued assistance throughout the project.

\section{REFERENCES}

Akhtar, S., Akoglu, G., Simon, S. and Rushmeier, H., 2017. Project Anqa: Digitizing and Documenting Cultural Heritage in the Middle East. International Archives of the Photogrammetry, Remote Sensing \& Spatial Information Sciences, 42.

Burns, Ross. 2005. Damascus: A History. London and New York: Routledge.

Centre, UNESCO World Heritage. "Ancient City of Damascus." UNESCO World Heritage Centre. Accessed February 21, 2019. http://whc.unesco.org/en/list/20.

Centre, UNESCO World Heritage. "World Heritage in Danger." UNESCO World Heritage Centre. Accessed February 21, 2019. https://whc.unesco.org/en/158/.

CIMS Development Team. 2018. Project ANQA. https://cims.carleton.ca/anqa/

Ciurea, C. and Filip, F.G., 2016. New Research on the Role of Virtual Exhibitions in Digitization, Preservation and Valorization of Cultural Heritage. Informatica Economica, 20(4), p.26.

Daskalakis, A.C., 2004. Damascus 18th and 19th Century Houses in the Ablaq-'Ajami Style of Decoration: Local and International Significance (Doctoral dissertation), 128-9.
Dhanda, A., Fai, S., Graham, K. and Walczak, G., 2017. LEVERAGING EXISTING HERITAGE DOCUMENTATION FOR ANIMATIONS: SENATE VIRTUAL TOUR. International Archives of the Photogrammetry, Remote Sensing \& Spatial Information Sciences, 42.

Google Development Team, Open Heritage. 2019. Google Arts \& Culture. Google.

https://artsandculture.google.com/project/cyark

Graham, K., Dhanda, A., Tousant, K., Weigert, A. and Fai, S., 2017, October. The VR Kiosk How observant passive VR storytelling enhanced the physical tour of parliament hill and disseminated the rehabilitation project. In 2017 23rd International Conference on Virtual System \& Multimedia (VSMM) (pp. 1-7). IEEE.

Ouimet, C., Gregg, J., Kretz, S., Chandler, C. and Hayes, J., 2015. Documentation and dissemination of the sculptural elements of Canada's Parliamentary Buildings: Methodology development and evolution, a case study. The International Archives of Photogrammetry, Remote Sensing and Spatial Information Sciences, 40(5), p.347.

(ICOMOS) International Council of Monuments and Sites, $2014 . \quad$ Ethical Principles https://www.icomos.org/images/DOCUMENTS/Secretariat/201 5/GA_2014_results/20150114-ethics-asadopted-languagecheckfinalcirc.pdf (8 February 2019)

Hayes, J., Fai, S. and White, P., 2014. Digitally-Assisted Stone Carving on Canada's Parliament Hill.

Herzfeld, E., 1942. Damascus: Studies in Architecture: I. Ars islamica, 9, pp.1-53.

Howell, N., 2017. Beyond Visualization: Spatial Presence and Virtual Heritage (Doctoral dissertation, Carleton University)

Pieraccini, M., Guidi, G. and Atzeni, C., 2001. 3D digitizing of cultural heritage. Journal of Cultural Heritage, 2(1), pp.63-70.

Salibi, K.S., 1957. The Maronites of Lebanon under Frankish and Mamluk Rule (1099-1516). Arabica, 4(Fasc. 3), pp.288303.

Santana Quintero, M., Blake, B. and Eppich, R., 2007. Conservation of Architectural Heritage: The Role of Digital Documentation Tools: The Need for Appropriate Teaching Material. International journal of architectural computing, 5(2), pp.239-253.

Shamir, S., 1963. As' ad Pasha al-'Azm and Ottoman rule in Damascus (1743-58). Bulletin of the school of Oriental and African studies, 26(1), pp.1-28.

Scholars Portal - Dataverse 2019. About

https://dataverse.scholarsportal.info (19 February 2019)

Sherban Cantacuzino, 1985. "Azem Palace," in Architecture in Continuity, ed. Sherban Cantacuzino (New York: Aperture), 165-169.

Tabba, Y., 1982. The architectural patronage of Nur al-Din, 1146-1174. New York University. 
Yastikli, N., 2007. Documentation of cultural heritage using digital photogrammetry and laser scanning. Journal of Cultural Heritage, 8(4), pp.423-427.

Yilmaz, H.M., Yakar, M., Gulec, S.A. and Dulgerler, O.N., 2007. Importance of digital close-range photogrammetry in documentation of cultural heritage. Journal of Cultural Heritage, 8(4), pp.428-433. 